\title{
A kompetenciák fontossága az életpálya során: az Észak-Alföld régió pedagógusainak vizsgálata
}

\author{
Kovács Edina
}

\author{
Debreceni Egyetem Felsőoktatási Kutató és Fejlesztő Központ (CHERD) \\ kovacs.edina.12@gmail.com
}

\begin{abstract}
A pedagógusok folyamatos szakmai fejlödése az utóbbi bö évtized kitüntetett szakmai kérdésévé vált. A szakmai fejlődést a kompetenciafejlődéssel definiáló életpályamodellek a tudományos párbeszédhez képest kevésbé komplex módon foglalkoznak nemcsak az intézményi és a környezeti hatásokkal, a pályaelhagyással, de a szakmai identitás és a reflektivitás fejlődésével is, ugyanakkor a pályán levő pedagógusok elsősorban az oket érintő szakpolitikai dokumentumokban találkoznak a kompetenciák fogalmával. Kutatásunk során azt vizsgáltuk, hogy a pályájuk első harmadában járó pedagógusok milyen kompetenciákat tartanak fontosnak, valamint, hogy mennyire elkötelezettek a pedagóguspálya mellett. Eredményeink azt mutatják, hogy a hazai életpályamodellben leírt kompetenciák fontossága nem differenciálódik pályaszakaszok szerint, így például a problémamegoldó kompetencia fejlesztését minden megkérdezett lényegesnek tartja, míg a reflektivitást minden pályaszakaszban kevéssé értékelték fontosnak a megkérdezettek.
\end{abstract}

Kulcsszavak: tanártovábbképzés, életpálya, folyamatos szakmai fejlődés

DOI: 10.37205/TEL-hun.2019.3-4.01

A pedagógusok szakmai fejlődésének szakmapolitikai definíciója jelenleg alapvetően a kompetenciafogalomra épül. E kompetenciasztenderdek az Egyesült Államokban fogalmazódtak meg először, és ezt adaptálták a közép-kelet-európai rendszerek többségében. E definíciók szerint a szakmai fejlődés elsősorban a tudás és a készségek fejlődése, valamint a tanári munkára való rálátás gazdagodása (Burden, 1982; Falus, 2006; Korom, 2010). Ugyanakkor a szakmai diskurzusban léteznek ezen túlmutató megközelítések, ahogy erre a későbbiekben kitérünk: a teljesség igénye nélkül ezek például a reflektivitást és a tanulói szerep transzformációját is kiemelik (Opfer és Pedder, 2011). A pedagóguskompetenciák fejlesztése már a képzésbe kerüléskor elkezdődik, és folytatódik a pálya lezárásáig. Az életpályamodellekből az is kitűnik, hogy a pálya korai szakasza különösen fontos a kompetenciák fejlődése szempontjából; ugyanakkor a pályaelhagyás megszakítja ezt a folyamatot, azaz a fiatal pedagógusok még a fontos szakmai készségek egy részé- 
nek megszerzése előtt tanítanak, majd a kiteljesedési szakasz előtt vagy alatt kerülnek nem tanári pályára.

Kutatásunk során épp ezért külön hangsúlyt fektettünk a pályájuk első harmadában járó pedagógusokra, miközben arra kerestünk választ, hogy a hazai minősítési rendszer alapján megfogalmazottak közül milyen kompetenciákat tartanak különösen fontosnak az észak-alföldi pedagógusok. A kutatás a Telemachus 2014 (TEachers' LEarning Motivation and AChievement in eastern part of HUngary Survey) adatbázisra épül. Az adatfelvételt a Debreceni Egyetem Felsőoktatási Kutató és Fejlesztő Központ (CHERD-Hungary) kutatói végezték, az adatbázis összesen 1056 válaszadó adatait tartalmazza.

Eredményeink azt mutatják, hogy a pályájuk első harmadában járó pedagógusok 20 százaléka fontolóra vette már a pálya elhagyását, elsősorban az anyagi helyzet és a megbecsültség hiánya miatt. A kompetenciák fontosságának vizsgálata pedig arra hívja fel a figyelmet, hogy azok nem differenciálódnak az egyes pályaszakaszok szerint, valamint, hogy a diákok teljesítményét leginkább befolyásoló készségek és célok kiemelt fejlesztésére vélhetően nagyobb figyelmet kellene fordítani az életpályamodellben.

\section{A pedagóguskompetenciák és az életpálya elméleteinek áttekintése}

A pedagógusok hatékonysága kulcsfontosságú elem az oktatás eredményessége szempontjából, ezzel szemben a rosszabb felkészültségủ és/vagy képességü pedagógusok kedvezőtlen hatása összegződve és hatványozottan jelenik meg a gyenge tanulói teljesítményekben (Cordingley mtsai., 2005; Mourshed és Barber, 2007; Mourshed, Chijioke és Barber, 2010). Ez az állítás már-már közhely a szakmai párbeszédben, azonban a „hatékony pedagógus” jellemzői, teljesítményének mutatói nem egyértelműek. A mérhető jellemzők ugyan ismertek, ilyen például a képesítés vagy az érdemjegyekkel, tudományos teljesítménnyel is kifejezhető szaktárgyi tudás, ezek azonban nem hatnak lineárisan a diákok eredményére. A kutatások szerint erősebb az összefüggés például a reflektivitással vagy a sokféle, adekvát tanítási módszer alkalmazásával: ezek azonban jóval nehezebben megragadhatók a különféle mérőszámok szintjén. Ugyancsak egyre hangsúlyosabban jelenik meg a pedagógiai tapasztalatok, a sokféle átélt osztálytermi helyzet fontossága, ezek kedvező hatása a tanári - és ennek eredményeképpen a tanulói - teljesítményre (Bacskai, 2015; Hargreaves és Fullan, 2012; Ko, Sammons és Bakkum, 2013; Kini és Podolsky, 2016). 
A pedagógusok szakmai tudásának megítélése, esetleges mérése során érdemes figyelembe venni a Hargreaves és Fullan (2012) által alkotott szakmai tőke-elméletet. Az elnevezés valamelyest félrevezető lehet azok számára, akik Bourdieu tőkeelméletére gondolnak: Hargreaves és Fullan ugyanis nem erre alapoz, hanem a tanárok hosszútávon létrejövő szakmai tőkéjét (professional capital) az üzleti, rövidtávon megtérülő tőkével (business capital) állítja szembe. A szakmai tőkét a szerzők szerint három összetevő alkotja: az első az emberi tőke (human capital), amely a tanár megszerzett végzettségeiben, egyéni minősítéseiben fejeződik ki. A második a szociális tőke ${ }^{1}$ (social capital), amely a társas viszonyok kezeléséhez, továbbá egymás szakmai támogatásához szükséges, és például egy intézmény tanárainak együttmúködésével, valamint az interakciók számával mérhető. A harmadik összetevő a döntéshozási tőke (decisional capital), amely a tanár kompetenciájából, megérzéseiből, ítélőképességéből és problémamegoldó képességéből tevődik össze. Utóbbival kapcsolatban a szerzők hangsúlyozzák, hogy teljes mértékben csak több éves szakmai gyakorlat alatt fejlődik ki, mivel az intuíciók és a szaktudás közti finom egyensúlyozás szükséges hozzá, a már ismert helyzetek tapasztalatának kreatív alkalmazása az új szituációkban. A tudatos pedagógus jellemzője a folytonos szakmai érdeklődés, a tanítás tervezése és fejlesztése, mindez csapatmunka keretében. (Hargreaves és Fullan, 2012).

Hargreaves elmélete, annak is elsősorban a döntéshozási tőkére vonatkozó része mind a pedagóguskompetenciák, mind a pályaelhagyás kérdéskörét érinti. Utóbbit azért, mert ha a tanárok nem maradnak elég hosszú ideig a pályán, akkor foglalkozási tőkéjüknek ez a része nem tud kiteljesedni: a szerzők emellett kiemelik, hogy attitűdbeli problémát is jelent, hogy minden harmadik pedagógus, akivel a diákok nap, mint nap találkoznak az osztálytermekben, tanítás helyett inkább valami mást szeretne csinálni. A pálya melletti elköteleződéssel, a pedagóguspálya elhagyásával foglalkozó tanulmányok egy része érinti a pedagóguspálya profeszszionális státuszát, ehhez kapcsolódóan a presztízs és az autonómia kérdését; rendszerint abban az összefüggésben, hogy a kiváló diákok pályára vonzásához és megtartásához a jelenlegi a szemi-professzió státuszból a professzió irányába lenne szükséges elmozdulni. Tanulmányunk közvetlenül nem érinti a szakmai fejlődés pedagógusközösséghez, intézményhez kötődő kérdéseit, így csak megemlítjük, hogy az elköteleződés témájában a szociális tőke is fontos és vizsgált tényező.

\footnotetext{
${ }^{1}$ A „social capital” fogalmat Hargreaves nem az inkább ismert társadalmi tőke értelemben használja, hanem kifejezetten a pedagógus társas helyzetekben való boldogulására, illetve az intézmény társas tőkéjének felmérésére.
} 
Más elméletek elsősorban a pályaszocializáció kudarcának tekintik a pálya elhagyását, ami különösen problematikus a végzettség megszerzését követő első öt évben: az egyes európai országokban eltérő a fiatal pályaelhagyók aránya, de mindenhol viszonylag magas, 10-40 százalék közötti (Ingersoll, 2002; CochranSmith, 2004; Nagy, 2004; Pusztai, 2015; Rapos, 2016).

A pedagóguskompetenciákhoz pedig azért kapcsolódik Hargreaves tőkeelmélete, mert a döntéshozási tőke mérhető jellemzői ezek közül kerülnek ki elsősorban: például a problémamegoldó képesség vagy a pedagógiai folyamat tervezése és az erre való reflektálás. A kompetenciafogalom definiálása ugyanakkor nem problémamentes: értelmezése a „képesség, készség” szinonimájától a komplex észleléstől a tevékenység végrehajtásáig tartó - rendszerig terjed, ráadásul mára szorosan összefonódott a szakmai fejlődés fogalmával is (Nagy, 2002; Falus, 2006; Trentinné Benkő, 2015).

A szakmai fejlődés egyik korai definíciója, amely még a kompetenciafogalom használatának általánossá válása előtt született, már tartalmazza azokat a fő elemeket, amelyek a mai meghatározásokban is megjelennek. Eszerint a szakmai fejlődés (és ehhez társulva a karrierút) a tudás és szakmai készségek, továbbá az attitűdök és a tanári munkára való rálátás gazdagodását, fejlődését jelenti, ezekhez kapcsolódik az újabb és újabb szakmai szintek teljesítése (Burden, 1982).

A pedagógusok szakmai fejlődését a későbbiekben számos aspektusból vizsgálták. Az egyes irányzatok részletes bemutatása túlmutat jelen tanulmány keretein, így csupán néhány kulcsfogalmat emelünk ki a következőkben. A szakmai fejlődésről szóló diskurzusok egy része a szervezett, illetve az informális tanulási alkalmakra, és - ehhez viszonyítva - a pálya egyes szakaszaira fókuszál (Gordon Győri, 2002; Desimone, 2009). Mások a reflektivitás fontosságát hangsúlyozzák; kapcsolódva akár a szakmai fejlődés informális (ön)szerveződéséhez vagy a tanulási-tanítási folyamat tervezéséhez, az ebben megnyilvánuló aktivitáshoz (Putnam és Borko, 2000; Zeichner, 2009).

Témánk szempontjából kiemelten fontosak azok a diskurzusok, amelyek szerint a szakmai fejlődés elsősorban a tanári kompetenciák fejlődését jelenti; beleértve az attitűdöket, az értékeket és a kognitív ismereteket, utóbbiakhoz azonban a tudás alkalmazása és az önreflexió is társul (Borko, 2004; Opfer és Pedder, 2011). Ezek értelmében a szakmai fejlődés minden esetben hosszú távú folyamat, amely nem független az iskolai környezettől és a diákoktól. A tanári kompetenciák fejlődése, fejlesztése elkezdődik a tanárképzésben, és optimális esetben folytatódik a tanítással 
töltött évek alatt. A folyamatos önfejlesztés segíti a tanárokat abban, hogy lépést tartsanak a tudományos, technikai változásokkal, és az intézménybe ágyazottság, valamint a pedagógiai folyamatokhoz kötött továbbképzés munkájuk hatékonyságát is növeli (Desimone mtsai., 2002; Villegas-Reimers, 2003; Rapos, 2016). A tanári tudás tartalmi szempontból több részre bontható: szaktárgyi tudás, pedagógiai tartalmi tudás (annak a tudása, hogyan kell tanítani a tantárgyi tartalmat), pedagógiai tudás (annak a tudása, hogyan kell tanítani általában). Gyakori az elméleti és gyakorlati tudás megkülönböztetése, ami arra utal, hogy a pedagógusok az elméleti ismeretek mellett saját tapasztalataik alapján is rendelkeznek tudással a tanításról, tanulásról (Ganser, 2000; Falus, 2001; Villegas-Reimers, 2003; Korom, 2010).

Tanulmányunk a szakmai kompetenciák fejlődését a hazai életpályamodellhez társítva vizsgálja. Ugyanakkor tisztában vagyunk azzal, hogy a szakmai szintek megjelenése a professzionális tanárrá válás során összetettebb folyamat, mint amit az életpályamodell magában foglal, illetve, hogy az életpályamodell nem feleltethető meg automatikusan a szakirodalomban leírt szinteknek. Hiszen az életpályamodell pedagógus II. szintjéről a továbblépés nem kötelező, és a további két szint - mesterpedagógus, illetve kutatótanár - viszonya sem lineáris, inkább mellérendelő. Ugyanakkor a hazai minősítési folyamat csak abban az évben - 2014ben - indult el, amikor kutatásunk adatfelvétele zajlott, így még nem volt mód a szakmai fejlődést, a kompetenciák fejlődését és a minősítési rendszer egyes szintjeit ténylegesen összekapcsoló kutatás tervezésére (Berliner, 2005; Szabó, 2013). Az sem rajzolódik ki tisztán, hogy az egyes szakaszokban hogyan, milyen támogatással történik a kompetenciák és a szakmai identitás fejlesztése. Amíg a tanárképzés gyakorlati évében a mentor egyértelműen a tanárjelölt mellett áll, és szerepe is jól definiált, addig a gyakornoki idő alatt már esetleges lehet bizonyos feltételek teljesülése (a 326/2013. kormányrendelet értelmében a mentor a nevelésseloktatással le nem kötött óraszáma terhére segíti a gyakornokot), a pálya későbbi szakaszairól pedig jelenleg formálódnak az első tapasztalatok (Stéger, 2015).

A pedagógus életpályát komplexebb módon leíró elemzések a pedagógus identitásának, professzionalizmusának kérdését is érintik. Sachs (2001) például arra a következtetésre jut, hogy a pedagógusi identitás multidimenzionális, hiszen minimálisan az oktatási szint (például általános iskolai tanár) és a műveltségterület, tudományág (például matematika- vagy testnevelő tanár) közösen alakítja, ezekhez csatlakoznak a különféle szereplők - például a szülők vagy az iskolavezetők szerepelvárásai, amelyekkel a pedagógus azonosulhat. Ennek következtében a 
karrierút nem független az egyén fejlődésétől, személyes és szakmai felismeréseitől, valamint az iskolai környezettől és az intézményen belüli kapcsolataitól sem. A komplex életpályaciklust mutatja be Lynn (2002) modellje (1. ábra).

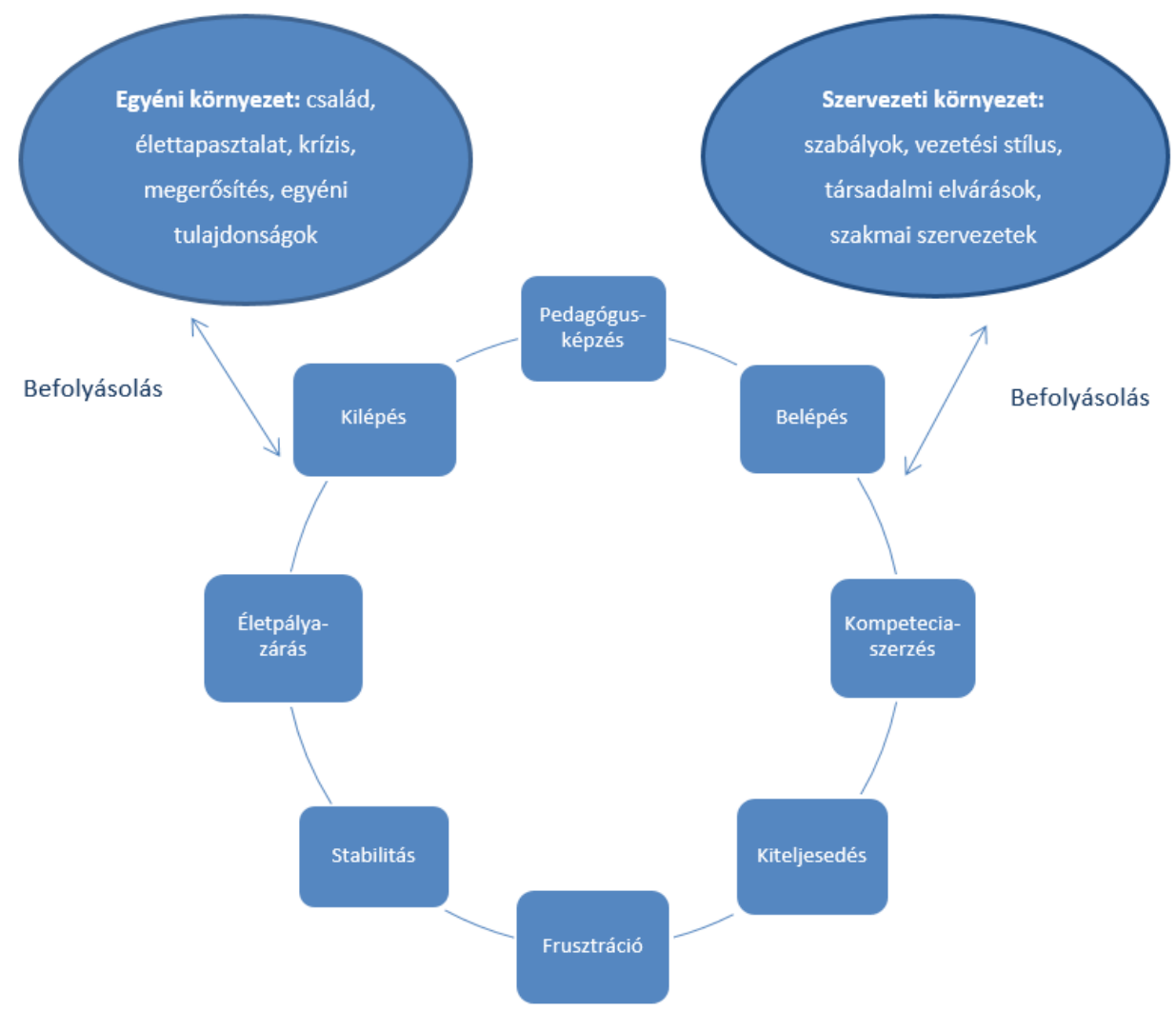

1. ábra: A tanári karrierkör és a környezeti hatások modellje. Forrás: Lynn, 2002.

Lynn modellje is megerősíti, hogy a tanári pálya korai szakasza különösen fontos a kompetenciák fejlődése szempontjából. A modellből a pályaelhagyás-elköteleződés vonatkozásában is kapunk információt: ha a pedagógus eljut a stabilitás szakaszába, akkor vélhetően már nem fog pályát változtatni, ugyanakkor - ha Hargreaves elméletét vesszük alapul - eddigre már rendelkezik a megfelelő döntéshozási tőkével. A következőkben bemutatott kutatás során ezért a pálya korai szakaszában járó pedagógusokat külön is megvizsgáljuk, miközben arra keresünk választ, hogy milyen kompetenciákat tartanak különösen fontosnak az északalföldi pedagógusok. Mivel kvantitatív kutatást végeztünk, a kompetenciák tényleges mérésére nem vállalkozhatunk, ugyanakkor lényegesnek tartjuk kideríteni, 
milyen mértékben tartják fontosnak a pedagógusok azokat a kompetenciákat, amelyek kitüntetettek a már említett döntéshozási tőke szempontjából: ilyen például a jó problémamegoldó készség vagy a pedagógiai folyamatok, tevékenységek tervezése és a megvalósításukhoz kapcsolódó önreflexiók.

\section{Az Észak-Alföld régió pedagógusainak vizsgálata}

\section{Módszerek és minta}

A kutatás a Telemachus 2014 (TEachers' LEarning Motivation and AChievement in eastern part of HUngary Survey) adatbázisra épül. Az adatfelvételt a Debreceni Egyetem Felsőoktatási Kutató és Fejlesztő Központ (CHERD-Hungary) kutatói végezték. Az adatfelvétel 2014. október 1. és november 15. között folyt, alapvetően papíralapú kérdőívek kitöltésével. A mintavétel során az állami és az egyházi intézményekből strukturált mintát vettünk. Az adatfelvételt ezt követően egy újabb, a Debreceni Egyetem pedagógusképzési vonzáskörzeteinek közoktatási intézményeiben történő online adatfelvétel egészítette ki, azokból az intézményekből, ahonnan papíralapon nem érkezett válasz, vagy ezek száma nem volt elegendő.

Az adatbázis összesen 1056 válaszadó adatait tartalmazza. A válaszadók jellemzően az Észak-Alföld régióból kerültek ki, de a Debreceni Egyetem továbbképzéseinek merítése ennél szélesebb körű, így - vélhetően az online adatfelvétel következtében - más megyék is képviseltetik magukat: legnagyobb arányban Borsod-Abaúj-Zemplén megye (10,6 százalék), valamint Békés megye (7 százalék). A válaszadók zöme (70 százaléka) az Észak-Alföld régió valamelyik megyéjében él: Hajdú-Bihar megyében 25,8 százalék, Jász-Nagykun-Szolnok megyében 16,4 százalék, Szabolcs-Szatmár-Bereg megyében 27,8 százalék.

A vizsgált régióban dolgozó és/vagy a régió továbbképzésein részt vevő pedagógusok jellemzőit tükröző minta nemek szerinti összetétele megfelel a magyar pedagógustársadaloménak. Az oktatási szintenkénti arányok ugyanakkor már kevésbé igazodnak a magyar pedagóguspopuláció arányaihoz. Míg az óvodákban a pedagógusok 20 százaléka, az általános iskolákban a fele és középfokú oktatásban (gimnáziumban, szakközépiskolában és szakiskolában) a fennmaradó 30 százaléka dolgozik, addig a mintában az óvodapedagógusok aránya 12,6 százalék, az általános iskolai tanároké 48,9 százalék, a középiskolában oktatóké 34,7 százalék, míg 3,8 százalék összevont intézményekben tanít.

Kutatási kérdésünk, hogy az életkor szerint tapasztalhatók-e szignifikáns eltérések a pedagógusok demográfiai jellemzőiben, pályaelhagyási szándékában, to- 
vábbá az egyes pedagóguskompetenciák vélt fontosságában. A Fónai $(2012,2014)$ által leírt deprofesszionalizációs folyamatok miatt feltételezzük, hogy a fiatalabb pedagógusok társadalmi státusa, anyagi helyzete kedvezőtlenebb az idősebbekénél. A kompetenciákra vonatkozóan feltételezzük, hogy a pályájuk elején járóknak a tanulás-tanítás folyamatához közvetlenül kapcsolódó kompetenciák lesznek fontosabbak, amilyen például a szaktárgyi tudás vagy a tanulás támogatása, míg az idősebbek, fejlettebb készségeiknek köszönhetően, inkább tartják fontosnak a pálya egészét érintő, a döntéshozási tőkéhez kapcsolható kompetenciákat, mint például a szakmai együttműködés vagy az önreflexió.

\section{Eredmények}

A pedagógusmintán belül, az összehasonlíthatóság érdekében korcsoportokat alakítottunk ki. Mivel a pályakezdés dátuma nem jelenik meg a kérdőívben, kénytelenek voltunk abból kiindulni, hogy a kérdezettek többsége a diploma megszerzését követően, a húszas éveiben kezdett tanítani. A pályakezdés első évében járók nem jelentek meg a mintában, így az első öt évre fókuszáltunk az első korcsoport létrehozásánál. Mivel a fiatalok aránya viszonylag csekély a mintán belül, végül 30 éves kornál húztuk meg az első korhatárt, hogy értékelhető arányú csoportot kapjunk. A minta fennmaradó részét dekádokra osztottuk, azzal a kiegészítéssel, hogy a 60 év feletti néhány fót a negyedik korcsoporthoz soroltuk (1. táblázat).

\begin{tabular}{lll}
\hline & $\%$ & $\mathrm{~N}$ \\
\hline 25-30 év közöttiek & 5,6 & 59 \\
31-40 év közöttiek & 20,6 & 218 \\
$41-50$ év közöttiek & 37,3 & 394 \\
51-66 év közöttiek & 36,5 & 385 \\
Összesen & 100 & 1056 \\
\hline
\end{tabular}

1. táblázat: Korcsoportonkénti megoszlás a mintán belül. Forrás: Telemachus 2014 (N=1056)

A 40 év alattiak körében szignifikánsan magasabb a férfiak aránya (2. táblázat). Ennek egyik oka lehet, hogy a 25-30 évesek körében a középiskolai tanárok aránya is szignifikánsan magasabb, és az oktatási szinteken felfelé haladva növekszik a férfiak aránya (az OECD adatai szerint az óvodákban 100 százalékos, az általános iskolákban 78 százalékos, a középiskolákban 68 százalékos a nők aránya). Ez azonban a 31-40 év közöttiek esetében már nem magyarázó tényező, így lehetséges, hogy a férfiak nagyobb arányú pályaelhagyása is szerepet játszik a nemek összetételének alakulásában. 


\begin{tabular}{llllll}
\hline & $25-30$ év & $31-40$ év & $41-50$ év & $51-66$ év & Összesen \\
\hline Férfiak & 22,4 & 24 & 15,5 & 13 & 16,8 \\
Nők & 77,6 & 76 & 84,5 & 87 & 83,2 \\
\hline
\end{tabular}

2. táblázat: A nemek aránya az egyes korcsoportokon belül (\%) Az összefüggés szignifikanciaszintje: $\mathrm{p}=0,004$. Forrás: Telemachus $2014(\mathrm{~N}=1056)$

A diplomás szülők aránya nem túl magas, mindössze a minta egyötödét jellemzi. További, nagyjából kétötödük esetében rendelkeznek a szülők érettségivel, ez elsősorban az anyák jellemző végzettsége. Korcsoportonkénti bontásban azt láthatjuk, hogy a fiatalabbak szülei valamivel nagyobb arányban rendelkeznek magasabb végzettséggel, ennek hátterében az is állhat, hogy az elmúlt évtizedekben egy-egy korosztályon belül nőtt az érettségizettek és a felsőfokú végzettségüek aránya.

A pedagógusok anyagi helyzetét illetően igyekeztünk felmérni az objektív mutatókkal mérhető státuszt, emellett arra is kíváncsiak voltunk, hogy a megkérdezett pedagógus hogyan ítéli meg saját helyzetét.

A szubjektív anyagi helyzetet ötfokú skálán mértük (a „sokkal jobb”-tól a „sokkal rosszabb”-ig). A változást illetően megoszlik a válaszadók véleménye: a tanárok egyharmada mondja, hogy az elmúlt tíz évben jobb vagy sokkal jobb lett az anyagi helyzete, egyharmaduk, hogy ugyanolyan maradt, és egyharmaduk érzi úgy, hogy kifejezetten rosszabb helyzetbe került. Az egyes korcsoportokat vizsgálva az látszik, hogy kizárólag a magukat „sokkal rosszabb” helyzetben érzők vannak többen a két fiatalabb korcsoportban $(\mathrm{p}=0,018)$, a skála négy további fokozata hasonlóan alakul.

Az objektív anyagi helyzetet egy 9 itemből álló kérdéscsoport mérte. Rákérdeztünk, hogy a pedagógus rendelkezik-e saját, illetve családi számítógéppel, interneteléréssel, okostelefonnal, táblagéppel, multifunkciós nyomtatóval, minimálisan 30 darab szakkönyvvel, személygépkocsival, továbbá önálló dolgozósarokkal vagy dolgozószobával. Ebből a 9 itemből képeztük az objektív anyagi helyzetet tükröző mutatót. A válaszok átlaga 5,98 volt. Az egyes korcsoportok között szignifikáns eltérést láthatunk: a legfiatalabbak és a legidősebbek kedvezőtlenebb helyzetben vannak, mint a közbenső két korcsoport (3. táblázat). Az anyagi mutató egyes itemeit külön is megvizsgálva az idősebbeknél fóként az okostelefonok alacsony aránya látszik, és ez lehet a rosszabb anyagi mutató egyik fő oka, míg a 25-30 éves korcsoport esetében a személygépkocsi és a saját dolgozósarok/dolgozószoba hiánya okozza az eltérést. 
Pedagógusképzés • 18(46), 2019/3-4.

\begin{tabular}{lll}
\hline & Átlag & Szórás \\
\hline 25-30 év közöttiek & 5,27 & 1,92 \\
31-40 év közöttiek & 6,09 & 1,85 \\
41-50 év közöttiek & 6,07 & 1,77 \\
51-66 év közöttiek & 5,51 & 2,18 \\
Összesen & 5,82 & 1,97 \\
\hline
\end{tabular}

3. táblázat: Az objektív anyagi helyzet alakulása korcsoportok szerint. Az összefüggés szignifikanciaszintje: $\mathrm{p}=0,000$. Forrás: Telemachus $2014(\mathrm{~N}=1056)$

A fiatalabbak közül szignifikánsan többen dolgoznak a tanári munkájuk mellett: a 25-30 évesek több mint egynegyede, a 31-40 évesek egyötöde végez pluszmunkát, ami az esetek mintegy kétharmadában tanári munka (4. táblázat).

\begin{tabular}{llll}
\hline & Nem dolgozik & Magánórát ad & Nem tanári munkája van \\
\hline 25-30 év közöttiek & 72,4 & 17,2 & 10,3 \\
31-40 év közöttiek & 79,4 & 12,1 & 8,5 \\
41-50 év közöttiek & 84,6 & 8,4 & 7 \\
51-66 év közötttiek & 89,8 & 4 & 6,2 \\
Összesen & 84,7 & 8,1 & 7,2 \\
\hline
\end{tabular}

4. táblázat: A pedagógusi állás mellett munkát vállalók korcsoportonként (\%). Az összefüggés szignifikanciaszintje: $\mathrm{p}=0,001$. Forrás: Telemachus $2014(\mathrm{~N}=1056)$

A megkérdezett pedagógusok mindössze tíz százaléka elégedetlen többé-kevésbé a munkahelyével, azaz kilenctizedük jól érzi magát az adott köznevelési intézményben, és ebben nincs szignifikáns eltérés az egyes korcsoportok között. A pálya esetleges elhagyásával kapcsolatos elképzelésekről két kérdést is feltettünk: elsőként arra kérdeztünk rá, hogy az elmúlt öt évben elgondolkoztak-e a pálya elhagyásán, majd arra, hogy elképzelhetőnek tartják-e, hogy tíz éven belül pályát változtassanak. A válaszok között a korcsoportonkénti eltérés mindkét esetben szignifikáns: a tíz éven belüli pályaelhagyásra a 25-30 és a 31-40 évesek közül nagyjából kétszer annyian hajlanak, mint az 51-66 éves korcsoport tagjai közül ( $p=0,000)$, míg az elmúlt öt évben főként a 31-40 év közöttiek gondolkoztak el a pedagóguspálya elhagyásán, ők is elsősorban a nem megfelelő körülmények, így például a megbecsültség és a rossz anyagi helyzet miatt (5. táblázat). 


\begin{tabular}{llllll}
\hline & $\begin{array}{l}\text { Nem, a } \\
\text { végzettségem } \\
\text { nem } \\
\text { versenyképes }\end{array}$ & $\begin{array}{l}\text { Nem, mert } \\
\text { szeretek } \\
\text { tanítani }\end{array}$ & \multicolumn{2}{l}{$\begin{array}{l}\text { Igen, mert nem Igen, a } \\
\text { váltak be az } \\
\text { körülmények } \\
\text { elképeléseim }\end{array}$} & $\begin{array}{l}\text { Igen, egyéb } \\
\text { okból }\end{array}$ \\
\hline $\begin{array}{l}\text { 25-30 év } \\
\text { közöttiek }\end{array}$ & 5,2 & 72,4 & 3,4 & 12,1 & 6,9 \\
$\begin{array}{l}31-40 \text { év } \\
\text { közöttiek }\end{array}$ & 3,4 & 63,7 & 7,8 & 18,1 & 6,9 \\
$\begin{array}{l}41-50 \text { év } \\
\text { közöttiek }\end{array}$ & 5,6 & 69,6 & 4,8 & 13,6 & 6,4 \\
$\begin{array}{l}51-66 \text { év } \\
\text { közöttiek }\end{array}$ & 5,5 & 78,2 & 2,5 & 8,5 & 5,2 \\
Összesen & 5,1 & 71,7 & 4,5 & 12,6 & 6,1 \\
\hline
\end{tabular}

5. táblázat: Az elmúlt öt évben a pályaelhagyást megfontolók korcsoportonként (\%). Az összefüggés szignifikanciaszintje: $\mathrm{p}=0,015$. Forrás: Telemachus $2014(\mathrm{~N}=1056)$

A pedagóguskompetenciákra vonatkozó kérdéssorunk többé-kevésbé lefedi a 326/2013. kormányrendeletben felsorolt kompetenciákat, de nem teljesen azonos vele. Az értelmezhetőség miatt a rendelet néhány megfogalmazását több elemre kellett bontani: például „a pedagógiai folyamatok és a tanulók személyiségfejlődésének folyamatos értékelése" két különálló részfeladat, amit két külön kérdésben jelenítettünk meg. Arra voltunk kíváncsiak, hogy a megkérdezettek saját életpályájukon mennyire tartanák fontosnak az adott kompetenciaterülethez kapcsolódó képzést, fejlesztést. A válaszlehetőségeket négyfokú Likert-skálán adtuk meg: az 1 az „egyáltalán nem fontos”, a 4 a „nagyon fontos” lehetőséget jelölte. A válaszadók közül kiemelkedően sokan szeretnének a hatékony problémamegoldást segítő képzéseket: 86,1 százalék válaszolt igennel erre a lehetőségre. Szintén nagy arányban igényelnék a tanulók személyiségének fejlesztésével (81,5 százalék), valamint a tanulók tanulásának támogatásával (80,6 százalék) kapcsolatos továbbképzéseket.

A skála másik végpontján két olyan képzés, illetve kompetenciaterület áll, amelyekkel kapcsolatban a megkérdezetteknek csupán a fele igényelne támogatást. Ezek az esélyteremtés, az integrációs tevékenység (50,5 százalék), valamint a pedagógiai folyamatok értékelése, elemzése (52 százalék). Utóbbi kapcsán érdemes megemlíteni, hogy a „pedagógiai tevékenység tervezése és ehhez kötődő reflexióra való képesség" is a kevésbé fontos feladatok közé került (6. táblázat). Úgy tünik tehát, hogy az önreflexió, noha a jelentőségét gyakran hangsúlyozzák, a pedagógusok napi gyakorlatában kevésbé tölt be igazán hangsúlyos szerepet. 
Pedagógusképzés • 18(46), 2019/3-4.

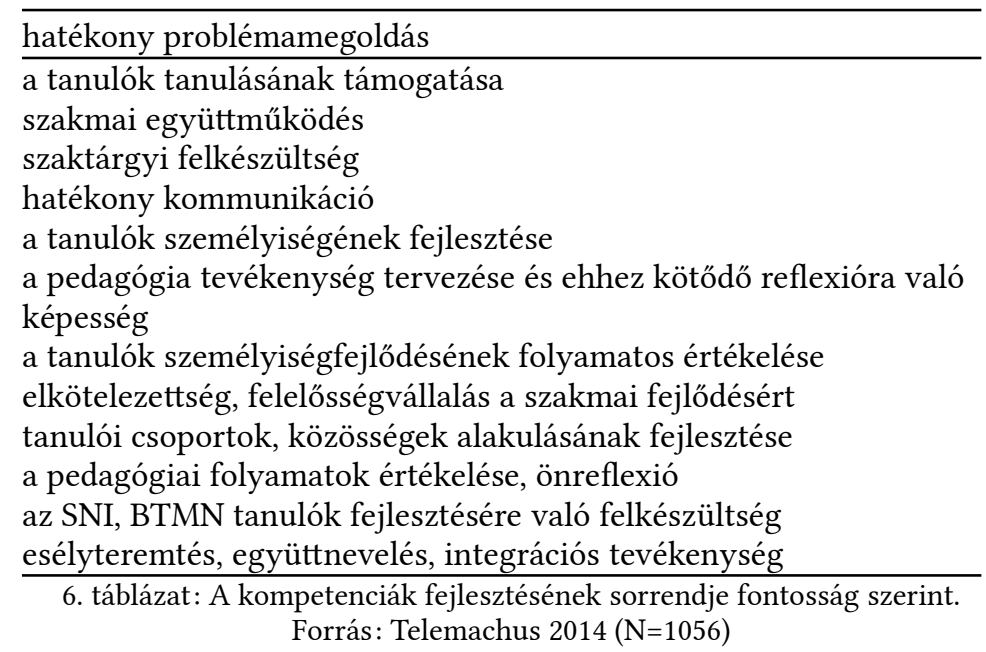

Kiemelendő az is, hogy a sajátos nevelési igényü tanulókkal kapcsolatos kompetenciák iránti igény a lista végére került, noha az OECD nemzetközi kutatásai, a Teaching and Learning International Survey (TALIS) 2009 és a TALIS 2013 is azt állapította meg, hogy a sajátos nevelési igényủ tanulók oktatása, a multikulturális nevelés és a tanórák kézbentartását támogató továbbképzések területén több lehetőséget igényelnének a megkérdezett tanárok. Elképzelhető, hogy jelen kutatás során a többi kompetencia iránti még nagyobb igény alakította csupán ezt a sorrendet, mégis jelzésértékü, hogy ez is, és az esélyteremtés is kevésbé tünik fontosnak az általunk megkérdezett pedagógusok számára.

$\mathrm{Az}$ esetek túlnyomó részében nem található érdemi eltérés az egyes korcsoportok válaszai, választásai között. Szignifikáns különbség $(\mathrm{p}=0,011)$ csupán az „elkötelezettség, felelősségvállalás a szakmai fejlődésért” kompetencia esetében mutatkozik: ezt az idősebbek valamivel nagyobb arányban tartják fontosnak, mint a fiatalabbak.

Megvizsgáltuk, hogy kimutatható-e kapcsolat a 13 item fontossága között, vannak-e olyan kompetenciaterületek, amelyek együttesen minősülnek fejlesztendőnek a pedagógusok egy-egy csoportja számára. Az elemzés során három faktort tudtunk létrehozni (7. táblázat). Az elsőbe tartozók számára a szakmai fejlődés és a pedagógiai folyamatok elemzése kiemelten fontos, emellett a kommunikáció, az együttműködés és a problémamegoldás hangsúlyos, így ez a faktor a „szakmaifejlődés-központú” elnevezést kapta. 
Szakmaifejlődésközpontú

Esély- és diákközpontú Szaktárgy-központú

\section{Elkötelezettség, felelős-}

ségvállalás a szakmai

fejlődésért

Hatékony problémameg-

oldás

Szakmai együttműködés

Hatékony kommuniká-

ció

A tanulók személyiség-

fejlődésének folyamatos

értékelése

A pedagógiai folyama-

tok értékelése, önrefle-

xió

Esélyteremtés, együttne-

velés, integrációs tevé-

kenység

Tanulói csoportok, kö-

zösségek alakulásának

fejlesztése

SNI, BTM tanulók fej-

lesztésére való felké-

szültség

A tanuló személyiségé-

nek fejlesztése

A tanulók tanulásának

támogatása

Pedagógiai tevékenység

tervezése, és ehhez kötő-

dő reflexióra való képes-

ség

Szaktárgyi felkészültség
0,16

0,61

0,53

0,71

0,69

0,83

0,73

0,65

0,68

0,46

0,63

$-0,07$

0,34

0,58

0,2

0,08

0,76

$-0,08$

0,26

0,73

0,35

0,4

0,24

0,59

0,09

$-0,04$

0,85

7. táblázat: Az egyes kompetenciaterületek fontossága (faktorszkórok). Varimax, KMO=0,885. Forrás: Telemachus $2014(\mathrm{~N}=1056)$ 
A második csoport a tanulók személyiségfejlesztésre helyezi a hangsúlyt, emellett fontosak számára a rangsorolásban egyébként kevéssé kitüntetett helyet elért területek, például az esélyteremtés és integrációs tevékenység, valamint az SNI, BTM tanulók fejlesztésére való felkészültség. A faktort ezért „esély- és diákközpontúnak" neveztük el. A harmadik csoport a szaktárgyi felkészültséget tekinti a legfontosabbnak, amihez a tanulók tanulásának támogatása és a pedagógiai tevékenység tervezése, és ehhez kötődő reflexióra való képesség kapcsolódik. Ennek alapján a faktor a „szaktárgyközpontú” nevet kapta. Az egyes faktorokon belül egyik korcsoport sem mondható szignifikáns mértékben alul- vagy felülreprezentáltnak, eltéréseket csupán nemek, valamint oktatási szintek szerint találunk. (Mivel kutatási kérdésünk a korcsoportonkénti eltérésekre vonatkozik, megjegyezzük, hogy a második faktorban tendenciaszerủen felülreprezentáltak a fiatalabb pedagógusok, de a különbség nem szignifikáns.)

Az esetleges pályaelhagyási szándék szempontjából szintén a második faktor mutatott szignifikáns, és fordított jellegü összefüggést $(\mathrm{p}=0,026)$ : akik ebbe tartoznak, azok jobban elkötelezettek a tanári pálya mellett, úgy tủnik, ez az a pedagóguskép, ami találkozik a valós elvárásokkal.

A kompetenciák fontosságának vizsgálata mellett a pedagógusmunka során elérendő szakmai célokra is rákérdeztünk. A 19 itemet úgy határoztuk meg, hogy egyenlő számban kapcsolódjanak a szakmai fejlődéshez és sokszínűséghez köthető célokhoz, a társas kapcsolatokkal, személyiségfejlesztéssel összefüggő célokhoz, illetve a kifejezetten tudásátadásra, oktatásra vonatkozó célokhoz. Az egyes célok fontosságát szintén négyfokú Likert-skálán jelölhették a válaszadók. Öszszességében elmondható, hogy a célok mindegyikét fontosnak találta a pedagógusok legalább 80 százaléka, az egyetlen kivétel a diákok szabadidős tevékenységének szervezése, amit egyharmaduk vélt kevéssé fontosnak. A leginkább szükséges célok közé került a diákok gyakorlati tudásának, személyiségének és kommunikációjának fejlesztése.

A megvalósítandó szakmai célok sorrendje, fontosság szerint:

- a diákok gyakorlati tudásának fejlesztése

- a diákok kommunikációjának fejlesztése

- a diákok felkészítése a nagybetűs életre

- a diákok személyiségének fejlesztése

- együttmüködés a kollégákkal

- a diákok elméleti tudásának fejlesztése 
- a lehető legtöbb ismeret átadása

- a tananyag folyamatos frissítése

- az értékelés megbeszélése a diákokkal

- együttműködés a szülőkkel

- a diákok kulturális tudatosságának fejlesztése

- a diákok személyes problémáinak megismerése

- a tanulást segítő osztálytermi rend kialakítása

- a diákok alapkészségeinek fejlesztése

- a lehető legtöbb oktatási módszer alkalmazása

- a pedagógiai újdonságok követése

- színvonalas továbbképzéseken való részvétel

- tanulmányi versenyekre való felkészítés

- a diákok szabadidős tevékenységének szervezése (Telemachus 2014 $(\mathrm{N}=1056))$

Látható, hogy a tágabban értelmezett pedagógiai tudáshoz köthető célok, mint például a sokféle oktatási módszer alkalmazása, vagy a pedagógiai újdonságok követése, alapvetően a lista második felében szerepelnek, hasonlóan a pedagóguskompetenciák fontosságának alakulásához.

Az egyes korcsoportok között szignifikáns eltérést a szakmai célok esetében is csak egyetlen item tekintetében találtunk. A diákok személyiségének fejlesztését a hosszabb ideje pályán lévők nagyobb arányban $(\mathrm{p}=0,008)$ értékelték „nagyon fontos”-nak, mint a fiatalabbak. Ugyanakkor ők sem vonták kétségbe e cél fontosságát, de nagyobb arányban elégedtek meg a „fontos” válasszal.

Megvizsgáltuk, hogy a kompetenciaterületek fontossága mutat-e összefüggést az egyes szakmai célok fontosságával. Valószínủleg a szakmai célok fontosságában kevéssé mutatkozó különbségek miatt mindössze egy cél esetében rajzolódott ki szignifikáns eltérés: „az értékelés megbeszélése a diákokkal” fontosabb azoknak, akik a kompetenciák közül a tanuló személyiségfejlesztését, tanulásának támogatását tartják a leglényegesebbnek.

\section{Összegzés}

Kutatásunk során azt vizsgáltuk, hogy az észak-alföldi pedagógusminta esetében életkor szerint tapasztalhatók-e szignifikáns eltérések a demográfiai jellemzőkben, a pályaelhagyási szándékban, valamint az egyes pedagóguskompetenciák fontosságában. A pedagógusok demográfiai és anyagi helyzetét a pálya egyes szakaszai- 
ban vizsgálva azt az eredményt kaptuk, hogy a szülők végzettsége önmagában nem támasztja alá a deprofesszionalizációs folyamatot, bár az oktatás expanziója miatt azt sem mondhatjuk, hogy teljesen ellentétes trendet figyelhetünk meg. Ahogyan azt feltételeztük, a fiatalabb pedagógusok anyagi helyzete kedvezőtlenebb az idősebbekénél, amit bizonyos mértékben indokol, hogy az anyagi javak megszerzésére hosszabb idő alatt nagyobb eséllyel kerül sor. Ugyanakkor a saját dolgozósarok vagy a személygépkocsi megléte, amelyek hiányát a fiatalabbak esetében láttuk, a húszas évek végén járva sem irreális elvárás - ráadásul a fiatalabbak körében viszonylag magas a pluszmunkát vállalók aránya, ami jelezheti, hogy a tanári fizetés önmagában nem elég ezek megszerzéséhez.

Mivel kutatásunk a jelenleg is pályán levő pedagógusokat vizsgálta, a tényleges pályaelhagyás vonatkozásában csupán annyit jegyezhetünk meg, hogy az életkor előrehaladtával indokolatlanul csökken a férfiak aránya a pedagógusok körében, ami lehet az ő nagyobb mértékủ pályaelhagyásuk jele. Ugyanakkor a most is tanító 40 év alatti pedagógusok 20 százaléka elgondolkozott az elmúlt öt évben a pálya elhagyásán, elsősorban a nem megfelelő körülmények, azon belül is a megbecsültség hiánya és a rossz anyagi helyzet miatt.

Az egyes pedagóguskompetenciák fontosságával kapcsolatos hipotézisünk lényegében nem igazolódott be: egyetlen kompetencia, az „elkötelezettség, felelősségvállalás a szakmai fejlődésért” volt szignifikánsan fontosabb a hosszabb ideje pályán lévőknek, mint a fiatalabb korosztályok tagjainak. Mivel a kompetenciák fejlődése a jelenlegi pályamodellekben szorosan összekapcsolódik a szakmai fejlődéssel, más-más területnek kellene hangsúlyossá válnia a kompetenciaszerzés, a kiteljesedés vagy a stabilitás fázisában. A differenciáltság hiányát megerősítik a szakmai célok vizsgálatával kapcsolatos eredmények is, amelyek esetében szintén a tanítási folyamathoz közvetlenül kötődő célok fontosabbak minden korcsoportban. Hogy mi az oka a vizsgált mintán belül a várható eltérések hiányának, az további kutatásokat igényel; okozhatja, hogy bizonyos kompetenciákat, például a reflektivitást, önreflexiót a tanárok alulértékelnek, lehetséges az is, hogy a továbbképzési kínálat bizonyos kompetenciákat jobban fejleszt, míg másokat többékevésbé figyelmen kívül hagy, és ez tükröződik a pedagógusok válaszaiban. Azt is érdemes lenne feltárni, mi okozza, hogy a hatékony problémamegoldás a pálya minden fázisában a leginkább fejlesztendőnek értékelt terület a megkérdezett pedagógusok szerint. 


\section{Irodalom}

Bacskai Katinka (2015): Iskolák a társadalom peremén. Alacsony státusú diákokat tanító eredményes tanárok. Belvedere, Szeged.

Berliner, David C. (2005): Szakértő tanárok viselkedésének leírása és teljesítményeik dokumentálása. Pedagógusképzés, 3 évf., 2. sz. 71-91.

Burden, Paul R. (1982): Implications of Teacher Career Development: New Roles for Teachers, Administrators and Professors. Paper presented at the National Summer Workshop of the Association of Teacher Educators, Slippery Rock, 1982. 08. 09 .

Cochran-Smith, Marilyn (2004): Stayers, leavers, lovers, and dreamers. Insights about teacher retention. Fournal of Teacher Education, 55 évf., 5. sz. 387-392.

Cordingley, Philippa - Bell, Miranda - Thomason, Sarah - Firth, Antonia (2005): The impact of collaborative continuing professional development (CPD) on classroom teaching and learning. Review: What do teacher impact data tell us about collaborative CPD? Research Evidence in Education Library, EPPI-Centre, Social Science Rese arch Unit, Institute of Education, University of London, London.

Desimone, Laura M. - Porter, Andrew C. - Garet, Michael S. - Yoon, Kwang Suk - Birman, Beatrice F. (2002): Effects of professional development on teachers' instruction: Results from a three-year longitudinal study. Educational evaluation and policy analysis, 24 évf., 2. sz. 81-112.

Desimone, Laura M. (2009): Improving impact studies of teachers' professional development: toward better conceptualizations and measures. Educational Researcher, 38. évf., 3. sz. 181-199.

Falus Iván (2001): A gyakorlat pedagógiája. In: Golnhofer Erzsébet és Nahalka István (szerk.): A pedagógusok pedagógiája. Nemzeti Tankönyvkiadó, Budapest. $15-27$.

Falus Iván (2006): Tanári képesítési követelmények - kompetenciák - sztenderdek. In: Demeter Kinga (szerk.): A kompetencia. Kihívások és értelmezések. Országos Közoktatási Intézet, Budapest. 299-309.

Fónai Mihály (2014): Joghallgatók - honnan jönnek és hová tartanak? DE AJK Dela Kiadó, Debrecen.

Fónai Mihály (2012): Tanárszakos hallgatók professzió-képe: a deprofesszionalizálódás esete? In: Pusztai Gabriella, Fenyő Imre és Engler Ágnes (szerk.): A tanárok tanárának lenni... Tanulmányok Szabó László Tamás 70. születésnapjára. Debreceni Egyetem Felsőoktatási Kutató és Fejlesztő Központ (CHERD), Debrecen. 109-128. 
Ganser, Tom (2000): An Ambitious Vision of Professional Development for Teachers. NASSP Bulletin, 84(618) évf., 6-12.

Gordon Győri János (2002): A tanárképzés és tanártovábbképzés japán modellje. Magyar Pedagógia, 102 évf., 4. sz. 491-515.

Hargreaves, Andy - Fullan, Michael (2012): Professional Capital. Transforming Teaching in Every School. Teachers College Press, New York.

Ingersoll, Richard (2002): The teacher shortage: A case of wrong diagnosis and wrong prescription. NASSP Bulletin, 86. 16-31.

Kini, Tara - Podolsky, Anne (2016): Does Teaching Experience Increase Teacher Effectiveness? A Review of the Research. Learning Policy Institute, Palo Alto.

Ko, James - Sammons, Pamela - Bakkum, Linda (2013): Effective teaching: a review of research and evidence. Berkshire: CfBT Education Trust.

Korom Erzsébet (2010): A tanárok szakmai fejlődése - továbbképzések a kutatásalapú tanulás területén. Iskolakultúra Online, 1 évf., 1-14.

Lynn, Susan K. (2002): The Winding Path. Understanding the Career Cycle of Teachers. The Clearing House: A Journal Of Educational Strategies, Issues And Ideas, 75. évf., 4. sz. 179-182.

Mourshed, Mona - Barber, Michael (2007): How the world's best-performing school systems come out on top. McKinsey \& Company.

Mourshed, Mona - Chijioke, Chinezi - Barber, Michael (2010): How the world's most improved school systems keep getting better. McKinsey \& Company.

Nagy József (2002): XXI. század és nevelés. Osiris Kiadó, Budapest.

Nagy Mária (2004): Pályakezdés, mint a pedagógusképzés középső fázisa. Educatio, 3 évf., 375-390.

OECD (2009): Teaching and Learning International Survey (TALIS). Összefoglaló jelentés az OECD Nemzetközi Tanárkutatás (TALIS) elsö eredményeiről. Oktatáskutató és Fejlesztő Intézet, Budapest.

OECD (2013): TALIS 2013 Results: An International Perspective on Teaching and Learning. DOI: 10.1787/23129638

Opfer, Darleen V. - Pedder, David (2011): Conceptualizing Teacher Professional Learning. Review of Educational Reserch, 81(3). 376-407.

Pusztai Gabriella (2015): Retenció és pályaszocializáció intézményfenntartó szerinti összehasonlításban - az állami és felekezeti pedagógusképzés hosszú távú hatásai. In: Pusztai Gabriella és Morvai Laura (szerk.): Pálya - modell. Igények és lehetóségek a pedagógusképzés változó rendszerében. Nagyvárad: Partium Könyvkiadó, Budapest: Új Mandátum Könyvkiadó, 195-206. 
Putnam, Ralph T. - Borko, Hilda (2000): What do new views of knowledge and thinking have to say about research on teacher learning? Educational Researcher, 29. évf., 1. sz. 4-15.

Rapos Nóra (2016): A támogatás értelmezései a személyes szakmai életúton. In: Vámos Ágnes (szerk.): Tanuló pedagógusok és az iskola szakmai tőkéje. ELTE Eötvös Kiadó, Budapest. 79-102.

Sachs, Judyth (2001): Teacher professional identity: competing discourses, competing outcomes. Fournal of Education Policy, 16. évf., 2 sz. 149-161.

Stéger Csilla (2015): Az Európai Unió tanárpolitikája és kapcsolatos tevékenységei - áttekintés és elemzés. In: Kispálné Horváth Mária (szerk.): Tanulmányok a pedagógusképzés 21. századi fejlesztéséhez. Nyugat-magyarországi Egyetem Regionális Pedagógiai Szolgáltató és Kutató Központ, Szombathely.

Szabó Mária (2013): A pedagógusok szakmai előmenetelének támogatása. In: Deák Máté, Erostyák János, Fischer Ferenc, Gerner Zsuzsanna és Kaposi József (szerk.): A tanárképzés jövőjérőll. Oktatáskutató és Fejlesztő Intézet, Budapest. 151-170.

Trentinné Benkő Éva (2015): A korai kétnyelvüség támogatására szolgáló pedagóguskompetenciák és pedagógusképzés. ELTE Eötvös Kiadó, Budapest.

Villegas-Reimers, Eleonora (2003): Teacher professional development: an international review of literature. Paris: UNESCO: International Institute for Educational Planning

Zeichner, Ken M. (2009). Teacher education and the struggle for social justice. Routledge, New York \& London. 


\section{The importance of comptences throughout the career: a study of educators from the North-Great Plain Region}

Teachers' continuous professional development has become an important professional discourse during the last decade. Career models that define the professional development with development of competences are less complex in the field of institutional effects, development of professional identity or reflectivity than the academic dialogues. However, in-service teachers mainly meet the concept of competencies in those policy documents that affect their work. This research examines what competences the teachers in their early years consider important and how committed they are to the teaching profession. Results show that the competences of the Hungarian career model do not differ according to career stages, e. g. the development of problem-solving competence is considered important by all respondents, while the importance of reflectivity is low in each career stages.

Keywords: further education, career, continuous professional development 